\title{
VALIDATION OF AN ALTERNATIVE METHOD FOR TOTAL NITROGEN ANALYSIS IN WATER SAMPLES
}

\author{
ADRIANA MUNTEAN ${ }^{\mathrm{a}}$, IRINA SMICAL ${ }^{\mathrm{b} *}$, ZOLTÁN TÖRÖK ${ }^{\mathrm{c}}$
}

\begin{abstract}
The current study presents the analytical validation method and performance characteristics of visible molecular adsorption spectrophotometry in determining the nitrogen concentration in water samples after the catalytic oxidation under controlled temperature and pressure conditions, using potassium peroxodisulfate, according to Romanian standard SR EN ISO 11905-1:2003. The quality of the calibration range (the determination coefficient of the calibration curve, the linearity and homogenity tests), the limit of detection, the limit of quantification, selectivity, robustness, recovery tests and the uncertainty calculation of the method allow the successful use of the method, using the specific conditions imposed by the analytical standard method.
\end{abstract}

Keywords: total nitrogen, potassium peroxodisulfate, validation.

\section{INTRODUCTION}

The Romanian regulation of monitoring the quality of surface waters [1] and various discharges of wastewaters into surface water [2] requires an analytical determination of nitrogen concentrations in various forms: ammonia, nitrate, nitrite, organic nitrogen, Kejdhal nitrogen and total nitrogen (TN).

The analytical techniques for determining the various nitrogen forms are multiple (volumetric analysis, potentiometry, spectrophotometry, liquid chromatography etc.), but the applied procedures must be standardized, fully validated and internationally accepted.

\footnotetext{
a Maramureș Water Management System, Someș-Tisa Basinal Water Administration, 2 Aleea Hortensiei, Baia Mare City, Maramureș County, Romania

b Faculty of Engineering, Technical University of Cluj-Napoca, North University Centre of Baia Mare, 62A Victor Babeş Street, Baia Mare City, Maramureş County, Romania

c Faculty of Environmental Science and Engineering, Babeș-Bolyai University of Cluj-Napoca, 30 Fântânele Street, Cluj County, Romania

*Corresponding author: irina.smical@yahoo.com
} 
In many laboratories, the streamline of the analytical process refers to the implementation of the safe analytical procedures, and efficient cost reduction of the analysis. Thus, the determination of total nitrogen by catalytic oxidation up to nitrates $\left(\mathrm{NO}_{3}{ }^{-}\right)$under controlled temperature and pressure conditions using potassium peroxodisulfate $\left(\mathrm{K}_{2} \mathrm{~S}_{2} \mathrm{O}_{8}\right)$, in accordance with the analysis SR EN ISO 11905-1: 2003, Annex C4 [4] has become usually applied as an alternative analytic method at digestion of water samples with Devarda alloy.

To ensure the results with high confidence level the implementation of a standardized method in an accredited laboratory is not enough, an assessment of fitness-for-purpose of the method by in-house confirmation is „sine-qua-non” [5, 6].

\section{RESULTS AND DISCUSSION}

\section{The characteristics assessment of the calibration curve}

The calibration was performed according to the standard method [4], in compliance with the scope of the work over the interval $(0.5-5.0) \mathrm{mg}$ $\mathrm{L}^{-1}\left(\mathrm{~N}-\mathrm{NO}_{3}{ }^{-}\right)$. The working standard solutions were obtained by appropriate dilutions of the stock solution of $1000 \mathrm{mg} \mathrm{N}-\mathrm{NO}_{3}-/ /$ concentration, derived from potassium nitrate (extra-pure salt, Merck, Germany). The calibration curve (Figure 1) fits to the Beer's law and was drawn by plotting the typical values of the absorbance due to $\mathrm{NO}_{3}{ }^{-}$(obtained by substracting the absorbance value measured at $275 \mathrm{~nm}$ from that at $210 \mathrm{~nm}$ ) against $\mathrm{N}$ $\mathrm{NO}_{3}{ }^{-}$concentration of the standards. By using the corrected absorbance of a sample, concentration was directly obtained from the calibration curve.

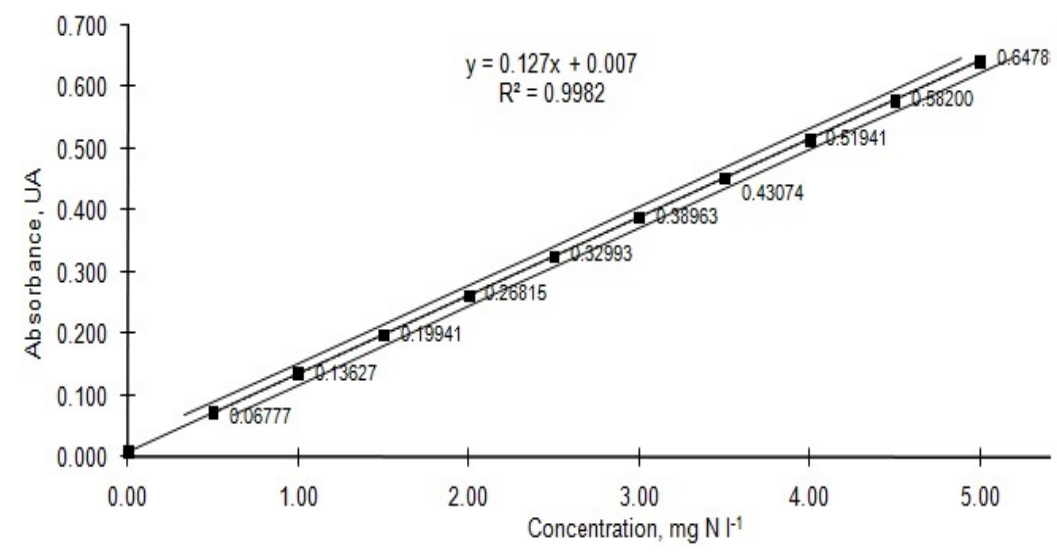

Figure 1. Regression curve and confidence interval 
The assessment of the performance characteristics of the calibration curve (Table 1) fulfills the performance criteria [7, 8] in terms of linear range: slope, intercept, coefficient of determination, standard deviation, variation coefficient of the method, tests of homogeneity dispersion and linearity.

Table 1. The performance characteristics of the calibration function

\begin{tabular}{|c|c|c|c|c|}
\hline \multicolumn{4}{|c|}{ Coefficient of determination $\left(R^{2}\right)$} & 0.9982 \\
\hline \multicolumn{4}{|c|}{ The slope of the calibration function (sensibility, b), *abs I mg-1 } & 0.127 \\
\hline \multicolumn{4}{|c|}{ The intercept (a, intersection with the axis Oy), ${ }^{*}$ abs } & 0.007 \\
\hline \multicolumn{4}{|c|}{ The residual standard deviation $\left(\mathrm{s}_{\mathrm{y}}\right), \mathrm{mg} \mathrm{l}^{-1}$} & 0.009 \\
\hline \multicolumn{4}{|c|}{ The standard deviation $\left(\mathrm{s}_{\mathrm{xo}}\right)$} & 0.067 \\
\hline \multicolumn{4}{|c|}{ The coefficient variation of the method $\left(\mathrm{V}_{\mathrm{xo}}\right), \%$} & 0.025 \\
\hline \multicolumn{5}{|c|}{ The homogeneity dispersions test } \\
\hline $\mathrm{s}_{1}{ }^{2 *} 10^{-5}$ & $\mathrm{~s}_{10^{2 *}}{ }^{2} 0^{-5}$ & $P G^{* *}$ & \multicolumn{2}{|c|}{$F^{* \star}(9 ; 9 ; 99 \%)$} \\
\hline 3.993 & 1.713 & 4.29 & \multicolumn{2}{|c|}{5.351} \\
\hline \multicolumn{5}{|c|}{ The linearity test } \\
\hline$P D^{* * *}$ & $\mathrm{DS}^{2}$ & Sy2 & \multicolumn{2}{|c|}{$\mathrm{F}^{* *}(8 ; 7 ; 99 \%)$} \\
\hline 0.5778 & 0.00522 & 0.0090 & \multicolumn{2}{|c|}{6.719} \\
\hline \multicolumn{5}{|c|}{$\begin{array}{l}\text { Note: }{ }^{*} \text { abs }- \text { absorbance units; }{ }^{* *} \mathrm{PG}-\text { ratio factor of the homogeneity } \\
\text { dispersions test }\left(\mathrm{s}_{1} / \mathrm{s}_{10}\right) ;{ }^{* *} \mathrm{PD}-\text { ratio factor of the linearity test; }{ }^{* *} \mathrm{~F}(9 ; 9 \text {; } \\
99 \%) \text { - Fischer value, at significance level }(99 \%) \text { with } 9,8 \text {; and } 7 \text { degrees of } \\
\text { freedom, respectively. }\end{array}$} \\
\hline
\end{tabular}

\section{The limit of detection (LOD) and the limit of quantification (LOQ)}

The Romanian regulation in force [1] provides a maximum concentration of $1.5 \mathrm{mg} \mathrm{L}^{-1}$ for the first class of surface waters. In accordance with this regulation, a target value for the quantification limit (LOQ) was set to $1.00 \mathrm{mg}$ $\mathrm{L}^{-1}$. The „3s criteria” - standard deviation multiplied by multiples of 3 - respectively 3,6 or 9 times - was applied to determinate LOD and LOQ, respectively [10, 23, 24].

To estimate LOD, the standard deviation was multiplied by 6 times and to estimate LOQ, the standard deviation was multiplied by 9 times [10, $23,24]$, from an experiment using simple replication of standard solution, at below of the expected LOD $=0.5 \mathrm{mg} \mathrm{N}^{-N_{3}}{ }^{-1} \mathrm{~L}^{-1}$, as it is shown in Table 2 . 
10 individual samples of a mixed solution (MS) containing nitrogen from glycine, ammonium, nitrite and nitrate (each one with a contribution of $25 \%$ nitrogen, from reference material, NIST traceable) were analysed in order to determine the precision at the asumated LOQ level to $1 \mathrm{mg} \mathrm{N}-\mathrm{NO}_{3}{ }^{-1} \mathrm{~L}^{-1}$. The relative standard deviation (RSD, \%), in terms of reproductibility, was $4.29 \%$ $(<10 \%)$, the recovery was $103.1 \%$ (between $95 \%$ and $105 \%$ ), both meeting the criteria of acceptability requirements imposed by the laboratory, as shown in the brackets.

Table 2. Results of the estimation of LOD and LOQ limits, using a standard solution of $0.5 \mathrm{mg} \mathrm{N}-\mathrm{NO}_{3}{ }^{-1} \mathrm{~L}^{-1}$

\begin{tabular}{|c|c|}
\hline 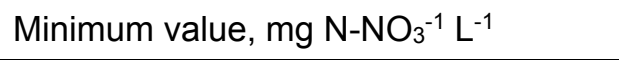 & 0.430 \\
\hline 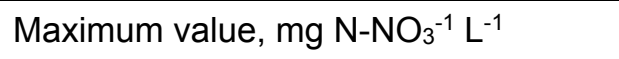 & 0.691 \\
\hline Mean value, $\mathrm{mg} \mathrm{N}^{-\mathrm{NO}_{3}{ }^{-1} \mathrm{~L}^{-1}}$ & 0.545 \\
\hline 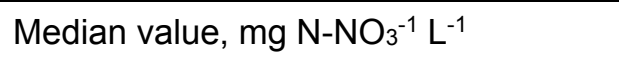 & 0.538 \\
\hline 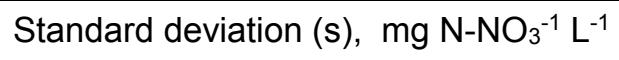 & 0.0817 \\
\hline $\mathrm{LOD}=6^{*} \mathrm{~s}, \mathrm{mg} \mathrm{N}-\mathrm{NO}_{3}{ }^{-1} \mathrm{~L}^{-1}$ (calculated) & 0.4903 \\
\hline 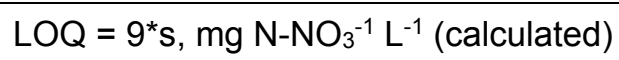 & 0.7354 \\
\hline Assumed LOD, mg N-NO${ }_{3}^{-1} \mathrm{~L}^{-1}$ & 0.500 \\
\hline Assumed LOQ, mg N-NO $3^{-1} \mathrm{~L}^{-1}$ & 1.000 \\
\hline
\end{tabular}

The specificity of the method was verified by testing the interference of the organic substances, in accordance with the standard method [4]. Five determinations were conducted using the synthetic samples with a concentration of $2 \mathrm{mg} \mathrm{L}^{-1}\left(\mathrm{~N}_{-} \mathrm{NO}_{3}{ }^{-}\right)$, enriched in potassium hydrogen phthalate (it inhibits the ability of the potassium peroxodisulfate in oxidation reaction) with the following concentrations, expressed as COD: $50 \mathrm{mg} \mathrm{O}_{2} / \mathrm{l}, 120 \mathrm{mg} \mathrm{O}_{2} / \mathrm{l}$ and $200 \mathrm{mg} \mathrm{O} / \mathrm{ll}$. The test results (table 3 ) verify the standard provisions [4] and impose the recommendation to use the method only for water matrices having the chemical oxygen demand less than $120 \mathrm{mg} \mathrm{O} / \mathrm{l}$ or dilutions of them.

The selectivity of the method was verified by comparing the total nitrogen (TN) concentrations obtained by using two methods and analyzing two samples of water with different matrices: surface water and household wastewater. Admitting a bias of $5 \%$ between these two methods, the selectivity of this method can be confirmed. 
Table 3. The specificity of the method

\begin{tabular}{|c|c|c|c|c|}
\hline Characteristics & $\begin{array}{l}\text { Mean, } \\
\mathrm{mg} \mathrm{N} \mathrm{L}^{-1}\end{array}$ & $\begin{array}{l}\text { Standard } \\
\text { deviation, } \\
\text { mg N L-1 }^{-1}\end{array}$ & $\begin{array}{l}\text { RSDr, } \\
\%\end{array}$ & $\begin{array}{l}\text { Acceptance condition [4]: } \\
\text { RSDr, } \% \leq 2.364\end{array}$ \\
\hline $\begin{array}{l}2 \mathrm{mg} \mathrm{L}^{-1}\left(\mathrm{~N}-\mathrm{NO}_{3}^{-}\right) \\
+50 \mathrm{mg} \mathrm{O}_{2} / \mathrm{l}\end{array}$ & 2.017 & 0.033 & 1.637 & Fulfilled \\
\hline $\begin{array}{l}2 \mathrm{mg} \mathrm{L}^{-1}\left(\mathrm{~N}-\mathrm{NO}_{3}^{-}\right) \\
+120 \mathrm{mg} \mathrm{O}_{2} / \mathrm{l}\end{array}$ & 1.969 & 0.045 & 2.309 & Fulfilled \\
\hline $\begin{array}{l}2 \mathrm{mg} \mathrm{L}^{-1}\left(\mathrm{~N}-\mathrm{NO}_{3}^{-}\right) \\
+200 \mathrm{mg} \mathrm{O} / \mathrm{l}\end{array}$ & 1.806 & 0.089 & 4.492 & Not fulfilled \\
\hline
\end{tabular}

The first method allows the calculation of the total nitrogen by

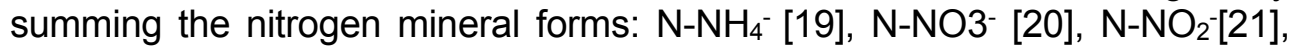
and organic nitrogen, calculated from the difference of Kjeldahl nitrogen [22] and ammonia nitrogen. The second method - water samples mineralization with potassium peroxodisulphate - allows the direct determination of total nitrogen using the calibration curve (Figure 1). From each matrices of water, 3 replicates of the original sample were individually analyzed.

The results (table 4) show that the method is applicable to the proposed aim.

Table 4. The selectivity of the method

\begin{tabular}{|c|c|c|c|}
\hline $\begin{array}{l}\text { Water } \\
\text { matrix }\end{array}$ & $\begin{array}{l}\text { The analyzed nitrogen } \\
\text { form }\end{array}$ & $\begin{array}{c}\text { Concentration } \\
\text { (mean of } 3 \\
\text { replicates) } \\
\text { mg N L-1 }^{-1}\end{array}$ & $\begin{array}{l}\text { Acceptance } \\
\text { condition: } \\
\text { Bias, } \% \\
\leq \pm 5.00\end{array}$ \\
\hline \multirow{6}{*}{$\begin{array}{l}\text { Surface } \\
\text { water }\end{array}$} & TN - present method & $1.017 \pm 0.144^{*}$ & \multirow{6}{*}{$\begin{array}{c}1.017= \\
0.968+4.82 \%\end{array}$} \\
\hline & Mineral nitrogen: & 0.360 & \\
\hline & Ammonium $\left(\mathrm{N}-\mathrm{NH}_{4}{ }^{+}\right)$ & 0.306 & \\
\hline & Nitrites $\left(\mathrm{N}-\mathrm{NO}_{2}^{-}\right)$ & 0.012 & \\
\hline & Nitrates $\left(\mathrm{N}-\mathrm{NO}_{3}{ }^{-}\right)$ & 0.042 & \\
\hline & Organic nitrogen & 0.608 & \\
\hline \multirow{6}{*}{$\begin{array}{l}\text { Household } \\
\text { wastewater }\end{array}$} & TN - present method & $6.401 \pm 0.825^{*}$ & \multirow{6}{*}{$\begin{array}{c}6.401= \\
6.544-2.23 \%\end{array}$} \\
\hline & Mineral nitrogen: & 4.796 & \\
\hline & Ammonium $\left(\mathrm{N}-\mathrm{NH}_{4}{ }^{+}\right)$ & 2.606 & \\
\hline & Nitrites $\left(\mathrm{N}-\mathrm{NO}_{2}{ }^{-}\right)$ & 0.744 & \\
\hline & Nitrates $\left(\mathrm{N}-\mathrm{NO}_{3}^{-}\right)$ & 1.446 & \\
\hline & Organic nitrogen & 1.748 & \\
\hline
\end{tabular}


For accuracy a certified reference material was used [15]. Usually, the difference between the certified value and the measured value $\left(\Delta_{\mathrm{m}}\right)$ must be lower than the expanded uncertainty obtained by combining the certified uncertainty $\left(\mathrm{u}_{\mathrm{CRM}}\right)$ with the uncertainty of repetability measurements $\left(\mathrm{u}_{\mathrm{m}}\right)[17$, 23]. For evaluating the results obtained for CRM (Battle-02, River Water Sample, Environment Canada) the „2-sigma limit” criterion was used, because this criterion was used by the producer (Table 5 ).

Table 5. The results obtained by using CRM (mean \pm 2 sigma limit)

\begin{tabular}{|c|c|}
\hline Certified value, g N L$^{-1}$ & Measured value, m N L$^{-1}$ \\
\hline $0.57 \pm 0.17$ & $0.600 \pm 0.07$ \\
\hline
\end{tabular}

The precision of the method in terms of the repeatability (same operator, and equipment, on the same day) and reproducibility (different operators and equipment, in different days) was evaluated by the coefficient of variation and in accordance with the provisions of Appendix A of the standard method [4]. The results obtained from analyzing the 6 independent samples, are presented in Table 6.

Table 6. The precision method in terms of the repeatability and reproducibility

\begin{tabular}{|c|c|c|c|}
\hline Sample & $\begin{array}{l}\text { Standard, } \\
2 \mathrm{mg} \mathrm{L}^{-1}\end{array}$ & $\begin{array}{c}\text { Estuary } \\
\left(2.02 \mathrm{mg} \mathrm{L}^{-1}\right) \text { with } \\
\text { addition of } \\
15 \mathrm{mg} \mathrm{L}^{-1}\end{array}$ & $\begin{array}{c}\text { Final effluent } \\
\left(6.401 \mathrm{mg} \mathrm{L}^{-1}\right) \text { with } \\
\text { addition of } \\
10 \mathrm{mg} \mathrm{L}^{-1}\end{array}$ \\
\hline Mean, $\mathrm{mg} \mathrm{L}^{-1}$ & 1.986 & 17.226 & 16.522 \\
\hline Found ${ }^{*} \mathrm{~S} r, \mathrm{mg} \mathrm{L}^{-1}$ & 0.038 & 0.327 & 0.171 \\
\hline Found ${ }^{* *} \mathrm{CV}_{\mathrm{r}} \%$ & 1.913 & 1.898 & 1.035 \\
\hline Imposed $\mathrm{CV}_{\mathrm{r},} \%$ & 2.364 & 2.252 & 1.195 \\
\hline Found ${ }^{* *} \mathrm{Sr}, \mathrm{mg} \mathrm{L}^{-1}$ & 0.066 & 0.883 & 0.761 \\
\hline Found ${ }^{* *} \mathrm{CV}_{\mathrm{R}} \%$ & 3.323 & 4.662 & 4.605 \\
\hline Imposed $\mathrm{CV}_{\mathrm{R}}, \%$ & 3.558 & 5.117 & 5.313 \\
\hline
\end{tabular}

The recovery was verified in compliance with the standard method [4] provisions (Annex B) using solutions with nitrogen originated from ethylenediaminetetraacetic acid disodium salt $\left(\mathrm{EDTANa}_{2}\right)$ and urea (Table 7). Recovery fulfill the conditions of the standard method [4] in Annex B. 
Table 7. Recovery of total nitrogen

\begin{tabular}{|c|c|c|}
\hline $\begin{array}{c}\text { EDTANa } 2 \text { solution, } \\
2 \mathrm{mg} \mathrm{L}^{-1} \\
\end{array}$ & $\begin{array}{c}\text { Urea solution, } \\
2 \mathrm{mg} \mathrm{N} \mathrm{L}^{-1}\end{array}$ & $\begin{array}{c}\text { Glycine solution, } \\
2 \mathrm{mg} \mathrm{N} \mathrm{L-1}\end{array}$ \\
\hline \multicolumn{3}{|c|}{ Average of the 6 determination } \\
\hline Recovery, \% & Recovery, \% & $\pm 0.20 \mathrm{mg} \mathrm{N} \mathrm{L}^{-1}$ \\
\hline 95.5 & 98.1 & +0.16 \\
\hline 93.2 & 95.8 & +0.12 \\
\hline 92.6 & 94.8 & -0.10 \\
\hline $\begin{array}{c}\text { Recommended: } \\
87 \% \div 98 \%\end{array}$ & $\begin{array}{l}\text { Recommended: } \\
91 \% \div 103 \%\end{array}$ & $\begin{array}{c}2.00 \pm 0.20 \\
\mathrm{mg} \mathrm{N} \mathrm{L}^{1}\end{array}$ \\
\hline Fulfilled criterium. & Fulfilled criterium. & Fulfilled criterium. \\
\hline
\end{tabular}

The uncertainty of the method was assessed $[9,10,14]$ using synthetic samples with a concentration at a quantification limit, $L O Q=1 \mathrm{mg}$ $\mathrm{N} \mathrm{L}^{-1}$, and real matrices: surface water and wastewater.

All possible sources of uncertainty were identified. Using propagation of uncertainty the combined standard uncertainty was calculated. The extended uncertainty was calculated by multiplying the combined standard uncertainty with a coverage factor ( $k=2$ for a level of confidence of $95 \%)$ [9].

The sources of uncertainty during the analysis identified and quantified [9] by processing a surface water sample are: the mean concentration (of repeatability) of 10 samples, the calibration curve plotting (preparation standard and calibration), equipment (UV-VIS), laboratory glassware and degree of recovery.

For the mentioned samples the expanded relative uncertainty for determination of the total nitrogen by catalytic oxidation with potassium peroxodisulfate is $13.8 \%$.

The expanded relative uncertainty for determination of the total nitrogen by catalytic oxidation with potassium peroxodisulfate was assumed at $15 \%$.

\section{CONCLUSIONS}

The method presents an adequate alternative for the determination of the nitrogen in water samples in a relative short time, minimizing the analysis cost. The implementation of the method for current use in laboratory imposed the necessity of verifying of all the method performance characteristics so that the results provide a high level of confidence. 
The performance parameters established and verified in laboratory, give objective evidences that the method is suitable for the purpose, and also that the standard method specifications are complied with and might provide results with a high confidence level.

\section{EXPERIMENTAL SECTION}

\section{Method, equipment and materials}

The principle of the standardized method [4] provides the oxidizing of the nitrogen forms up to nitrates (free and ammonia nitrogen, nitrates, nitrites and organic compounds with nitrogen) in water samples.

The mineralization of water samples (maximum of $50 \mathrm{ml}$ of the water sample or dilution of sample) is carried out in heat-resistant glass bottles, in alkaline medium ( $\mathrm{pH}=9.7)$ with a mix solution $(10 \mathrm{ml}$ at $50 \mathrm{ml}$ water samples) of potassium peroxodisulfate, boric acid and sodium hydroxide, in precise conditions of temperature $\left(120^{\circ} \mathrm{C}\right.$ ) and pressure (maximum $40 \mathrm{kP}$ ), in an autoclave, for 30 minutes.

After mineralization, the nitrogen concentration in the obtained solutions is determined from a calibration curve previously drawn using potassium nitrate solution (p.a., Merck manufacturer), in a concentration range of $0.5-5.0 \mathrm{mg} \mathrm{N}^{-N^{2}}{ }_{3}^{-} \mathrm{L}^{-1}$. The procedure consists in measuring the net absorbance $(\mathrm{nm})$ (subtract the value of the absorbance reading at $275 \mathrm{~nm}$ from the reading at $210 \mathrm{~nm}$ ), by using ChemLab software of the molecular absorption spectrophotometer Agilent, type 8453, metrological tested and calibrated.

Analytical purity reagents (p.a.), certified solutions as reference materials, CertiPur Merck [11, 12, 13] and certified reference materials Battle-02, River Water Sample, Environment Canada [11, 12, 13], glassware A class and benchmarked measurement equipment were used.

The performance characteristics of the calibration curve were established by the statistical testing of the dispersion linearity and homogeneity $[7,8]$. The acceptability criteria of the other parameters analysed for the fitness-for-purpose are in accordance with the standard method [4], the European and international guides [9-18] regarding the quality assurance of analytical chemistry measurements. 


\section{REFERENCES}

1. Ministerial Order no. 161 of 16 February 2006, for approval of the Norms on surface water quality classification in order to establish ecological status of the water bodies (in Romanian).

2. Technical Framework of the Romanian Government for approval of the maximum limits loading with pollutant allowed at industrial and urban waste water evacuation in the natural receptors, 2002 web link: http://www.gnm.ro/otherdocs/nsbhrtjqp.pdf

3. SR ISO 10048:2001, Water quality. Determination of nitrogen. Catalytic digestion after reduction with Devarda's alloy.

4. SR EN ISO 11905-1:2003, Water quality. Determination of nitrogen. Part 1: method using oxidative digestion with peroxodisulfate. Annex C4 - Nitrates determination.

5. SR EN ISO/CEI 17025:2005, General requirements for the competence of testing and calibration laboratories.

6. M., Omota, L., Lazarescu, C., Neamtu, Bioflux, Proenvironment, 2011, 4, p. 131138, web link:

http://journals. usamvcluj.ro/index.php/promediu/article/viewFile/6204/5637.

7. SR ISO 8466-1:1999, Water quality. Calibration and evaluation of analytical methods and estimation of performance characteristics. Part 1: Statistical evaluation of the linear calibration function.

8. SR ISO 8466-2:1999, Water quality. Calibration and evaluation of analytical methods and estimation of performance characteristics. Part 2: Calibration strategy for nonlinear second calibration function.

9. Eurachem/CITAC Guide: Quantifying Uncertainty in Analytical Measurement, 2012, available from: $h$ ttp://www.eurachem.org.

10. B. Magnusson and U. Örnemark (eds.) Eurachem Guide: The Fitness for Purpose of Analytical Methods - A Laboratory Guide to Method Validation and Related Topics, $2^{\text {nd }}$ edition, 2014, web link: http://www.eurachem.org.

11. Guide ISO 30:1992/Amd.1:2008, Revision of definitions for references material and certified reference material.

12. Guide ISO 32:1997, Calibration in analytical chemistry and use of certified reference materials.

13. Guide ISO 33:2000, Uses of certified references materials.

14. Guide ISO/CEI 98-3:2010, Uncertainty of measurement - Part 3: Guide to the expression of uncertainty in measurement. 
15. SR ISO 5725-6:2002 - Accuracy (trueness and precision) of measurement methods and results - Part 6: Use in practice of accuracy values.

16. H., Hovind, B., Magnusson, M., Krysell, U., Lund, I., Makinen, „Internal Quality Controll - Handbook of Chemical Laboratories", 2011, ed. $4^{\text {th }}$, p. 3- 25.

17. T., Linsinger, Application Note 1, Comparison of a measurement results with certified value, European Commission-Joint Research Center Institute for Reference Material and Measurements, 2005, web link: http://www.bam.de/en/fachthemen/referenzmaterialien/referenzmaterialien_m edien/erm_application_note_1_en.pdf

18. Journal AOAC Int, Official Methods of Analysis Guidelines for Standard Method Performance Requirements, 78(5), 2012, web link: http://www.aoac.org/imis15_prod/AOAC_Docs/StandardsDevelopment/Collab orative_Study_Validation_Guidelines.pdf

19. SR ISO 7150-1:2001 - Water quality. Determination of ammonium. Part 1: Manual spectrometric method.

20. SR EN 26777/C91:2006 - Water quality - Determination of nitrite - Molecular absorption spectrometric method.

21. SR ISO 7890-3:2000 - Water quality. Determination of nitrate. Part 3: Spectrometric method using sulfosalicylic acid.

22. SR EN 25663: 2000 - Water quality. Determination of Kjeldahl nitrogen. Method after mineralization with selenium.

23. L. Senila, M. Miclean, O. Cadar, M. Senila, M. Kovacs, M.A. Hoaghia, Studia UBB Chemia, 2016, 61, 345.

24. C. Drăghici, C. Jelescu, C. Dima, C. Sică, E. Chirilă, S. Dobrinaș, A. Soceanu, Studia UBB Chemia, 2012, 58, 93. 